S 533

. 18

LIBRARY OF CONGRESS

|||||||||||||||||||||||||||||||||||||||||||

|||||||||||||||||||||||||||||||||||||||||||||||||||||

00004066984 


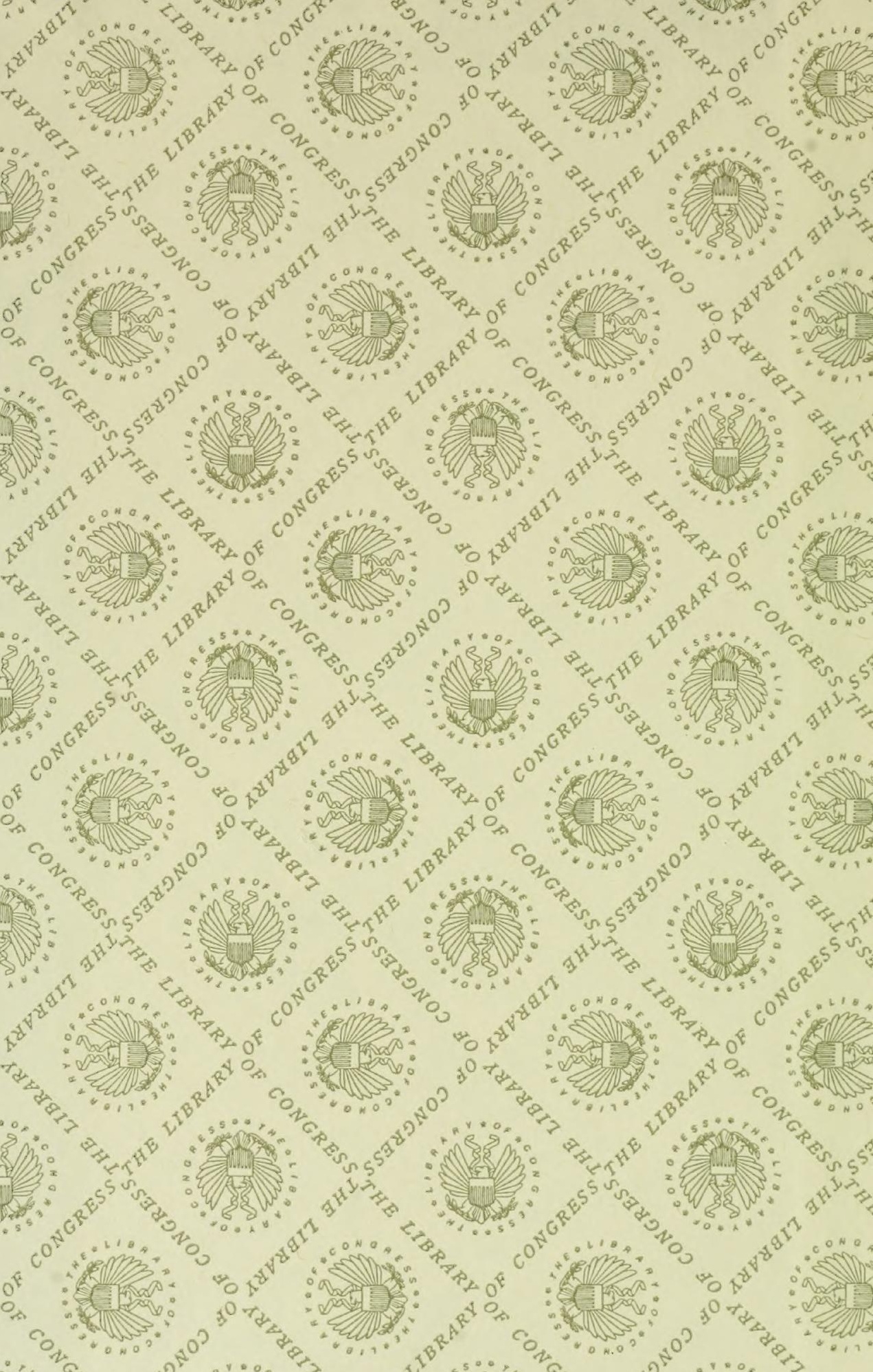




U. S. DEPARTMENT OF AGRICULTURE, OFFICE OF EXPERIMENT STATIONS, A. C. TRUE, Director.

$\longrightarrow$

\section{THE AMERICAN SYSTEM}

OF

\section{GRICULTURAL EDUCATION.}

BY

A. C. TRUE and DICK J. CROSBY, Of the Office of Experiment Stations.

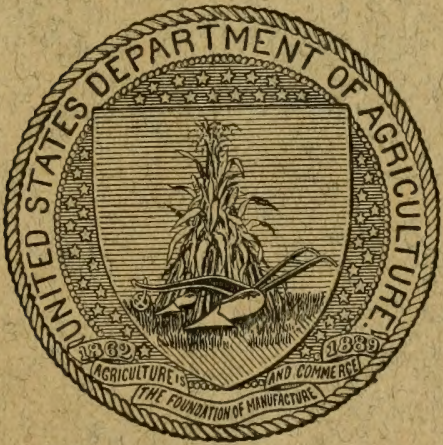

WASHINGTON:

GOVERNMENT PRINTING OFFICE.

1904 . 


\section{THE AGRICULTURAL COLLEGES.}

Alabama-Auburn: Charles C. Thach. $a$ Normal: Wm. H. Councill. $a$ Tuskegee: Booker T. Washington, $b$

Arizona-Tucson: Kendrick C.Babcock. $a$ Arkansas - Fayetteville: Henry. S. Hartzog. $a$

California-Berkeley: Benjamin Ide Wheeler. $a$

CoLorado-Fort Collins: Barton O. Aylesworth. $a$

ConNecticuT-Storrs: R. W. Stimson. $a$

Delatira-Newark: Geo. A. Harter. $a$ Dover: W. C. Jason. $a$

FlonidA-Lake City: Thos. H. Taliaferro. $a$ Tallahassee: Nathan B. Young.

Georgia-Athens: H. C. White. $a$ College: R. R. Wright. $a$

IDAно-Moscow: J. A. McLean. $a$

Illinois-Urbana: Andrew S. Draper. $a$

INDiANA-Lafayette: Winthrop Ellsworth Stone. $a$

Iowa-Ames: Albert Boynton Storms. $a$

Kansas-Manhattan: Ernest R. Nichols. $a$

Kentucky-Lexinglon: J. K. Patterson. $a$

Frankfort: James S. Hathaway, $a$

Lovisiana-Baton Rouge: Thos. D. Boyd. $a$ New Orleans: H. A. Hill.a

Maine-Orono: George Emery Fellows. $a$

Maryland-College Park: R. W. Silvester. $a$ Princess Anne: Frank Trigg. $b$

Massachusetrs-Amherst: Henry H. Goodell. $a$

Michigan-Agricultural College: J. L. Snyder. $a$

Minnesota-St. Anthony Park, St. Paul: Cyrus Northrop. $a$

MississippI-Agricultural College: J. C. Hardy ${ }^{a}$ Westside: W. H. Lanier, $a$

Missouri-Columbia: R. H.Jesse $a$ Jefferson City: B. F. Allen. $a$

Montana-Bozeman: James Reid.a

Nebraska-Lincoln: E. Benjamin Andrews. $c$

$a$ President.
Nevada-Reno: Joseph E. Stubbs.a

New Hampshire-Durham: Wm. D. Gibbs. $a$

New JeRSEY-New Brunswick: Austin Scott. $a$

New Mexico-Mesilla Park: Luther Foster. $a$

New Yonk-Ithaca: Jacob Gould Schurman. $a$

North Carolina-West Raleigh: G. T. Winston. ${ }^{a}$ Greensboro: James B. Dudley. $a$

NoRth DAкотA-Agricultural College: J. H. Worst. $a$

OHo-Columbus: William Oxley Thompson. $a$

Oкцанома-Stillwater: Angelo C. Scott. $a$ Langston: Inman E. Page. $a$

OREGON-Corvallis: Thos. M. Gatch. $a$

Pennsylvania-State College: George W. Atherton. $a$

RHODE IsLAND-Kingston: Kenyon L. Butterfield. $a$

South Carolina-Clemson College: P. H. Mell. a Orangeburg: Thomas E. Miller. $a$ South DaкотA-Brookings: James Chalmers. $a$

TenNessee-Knoxville:

Texas-College Station: David F. Houston. a Prairieview: E. L. Blackshear. $a$ UTAH-Logan: W. J. Kerr $a$

VERMONT-Burlington: M. H. Buckham. $a$ VIRGINIA-Blacksburg: J. M. McBryde, a Hampton: H. B. Frissell. $b$

WAshingtoN-Pullman:-E. A. Bryan. ${ }^{a}$

West Virginia - Morgantown: D. B. Purinton. a Institute: J. McHenry Jones. ${ }^{b}$ Wisconsin-Madison: Chas. Richard Van Hise. $a$

Wroming-Laramie: Charles, Willard Lewis, $a$

b Principal. 
U. S. DEPARTMENT OF AGRICULTURE, OFFICE OF EXPERIMENT STATIONS,

A. C. TRUE, Director.

\section{THE AMERICAN SYSTEM}

$\mathrm{OF}$

\section{AGRICULTURAL EDUCATION.}

BY

A. C. TRUE and DICK J. CROSBY, Of the Office of Experiment Stations.

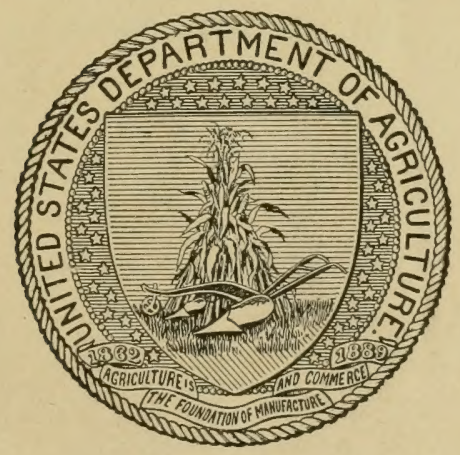

WASHINGTON:

GOVERNMENT PRINTING OFFICE.

1904. 


\title{
$5^{5} x^{3} 8$
}

\author{
A. C. True, Ph. D.-Director. \\ E. W. Allen, Ph. D.-Assistant Director and Editor of Experiment Station Record. \\ W. H. BEAL-Chief of Editorial Division. \\ JoHn НАмптоN-Farmers' Institute Specialist. \\ C. E. Johnston-Chief Clerk.
}

EDITORIAL DEPARTMENTS.

E. W. Allen, Ph. D., and H. W. Lawson-Chemistry, Dairy Farming, and Dairying. W. H. BeAL-Agricultural Physics and Engineering.

Walter H. Evans, Ph. D.-Botany and Diseases of Plants.

C. F. Langworthy, Ph. D.-Foods and Animal Production.

J. I. Schulte-Field Crops.

E. V. Wilcox, Ph. D.-Entomology and Teterinary Science.

C. B. Sмгтн-Horticulture.

D. J. Crosby-Agricultural Institutions. 


\section{LETTER OF TRANSMITTAL.}

\section{U. S. Department of Agriculture, \\ Office of Experiment Stations,}

Washington, D. C., May 20, 1904.

SiR: I have the honor to transmit herewith a brief general account of the American system of agricultural education, which contains descriptions of departments of original research and graduate study in agriculture, agricultural colleges and the various grades of instruction provided by them, secondary schools of agriculture, and the work along agricultural lines in primary schools. This account has been prepared primarily for distribution in connection with the exhibit of the colleges of agriculture and mechanic arts and experiment stations at the Louisiana Purchase Exposition. There is need of popular descriptive literature relating to these institutions and their exhibit for distribution among those attending the exposition. This is the first of a series of papers prepared to meet this need, and I recommend its publication as a document of this Office.

Respectfully,

Hon. James Wilson,
A. C. True,

Director. 


\section{CONTENTS.}

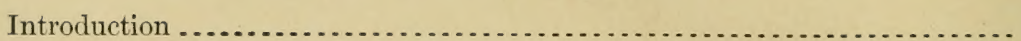

Departments of original research and graduate study in agriculture ..........

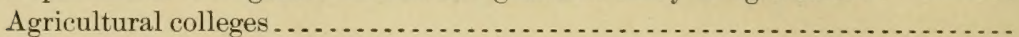

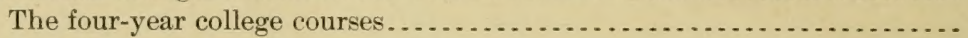

The short and special courses .....................................

Agronomy ...........................................

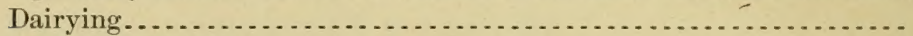

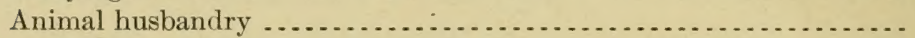

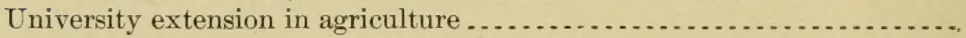

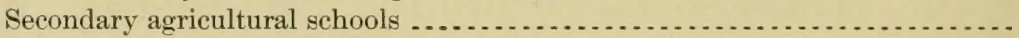

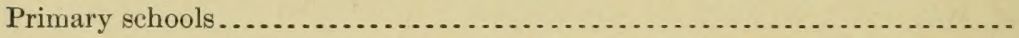

Page.

\section{ILLUSTRATIONS.}

Plate I. Agricultural Building, Ohio State University

II. Agricultural Building, University of Illinois

III. Agricultural Hall, South Carolina Agricultural and Mechanical College

IV! Agricultural Building, Wisconsin University

V. California Polytechnic School-recitation and administration building on left, dormitory on right

VI. Fig. 1.-Main building, Marathon County School of Agriculture and Domestic Economy. Fig. 2.-Main building, Dunn County School of Agriculture and Domestic Economy .....................

VII. Fig. 1.-A country school garden, District 58, Winnebago County, Ill. Fig. 2.-Potatoes raised by pupils in the Practice School of Vermont State Normal School .

VIII. Fig. 1.-George Putnam School Gardens, Boston. Fig. 2.-A school garden at Dewitt Clinton Park, in the heart of New York City ... 


\section{THE AVIERICAN SYSTEII OF AGRICULTURAL EDUCATION.}

By A. C. True and Dick J. Crosbr,

Of the Office of Experiment Stations.

\section{INTRODUCTION.}

The American system of agricultural education includes a number of different classes of institutions which, taken together, provide all grades of instruction in agriculture from graduate courses leading to the doctor's degree to nature-study courses in the kindergarten and the primary school. These institutions may be considered under four general heads: (1) Departments of original research and graduate study in agriculture, (2) agricultural colleges, (3) secondary schools of agriculture, and (t) primary schools. The secondary and primary instruction in agriculture is of comparatively recent development, but is well worthy of consideration in this connection. The graduate and collegiate courses, on the other hand, are well established and take rank with the best agricultural courses in the much older universities and colleges of Europe.

The American institutions for instruction and research in agriculture are brought together to constitute a national system of higher education in the sciences and industries through the Association of American Agrieultural Colleges and Experiment Stations, the Oftice of Experiment Stations of the Department of Agriculture, and the Bureau of Education of the Department of the Interior, each of these agencies being entitled to membership in the association. This association was organized in Washington October 1s, 1857, and has since been rery active and efficient in its efforts to promote agricultural education. At its convention in 1894 it appointed a committee on entrance requirements, courses of study, and degrees, whose final report, presented two years later, was adopted. This report recommended (1) physical geography; (*) United States history; (3) arithmetic, including the metric system; (4) algebra to quadratics; (5) English grammar and composition, together with the English requirements of the New England Association of Colleges and Preparatory Schools, and (6) ancient, general, or English history as a standard of entrance requirements for college courses, and suggested that all rolleges unite in requiring the first five subjects as a minimum for admission to their 
lowest collegiate classes. The committee also urged that the colleges require (1) mathematies through algebra, geometry, and trigonometry; (2) physics and chemistry, with laboratory work in each; (3) English language and literature; $(t)$ other languages (at least one modern); (5) mental science and logic or moral science; (6) constitutional law, and (7) social, political, or economic science for four-year courses leading to a bachelor's degree.

In 1895 the association appointed a standing committee on methods of teaching agriculture, which has since presented eight reports of progress. The first report ${ }^{a}$ was devoted to recommendations regarding agricultural nomenclature and a review of agricultural education in European countries. The second report ${ }^{b}$ was deroted to suggestions regarding the subjects to be included in a four-year course in agriculture. In its third, fourth, and fifth reports ${ }^{c}$ the committee suggested outlines for the courses in agronomy, zootechny, agrotechny, rural engineering, and rural economics. The sixth report was deroted to methods and facilities for teaching agronomy in the agricultural colleges, the serenth" to secondary courses in agriculture, and the eighth ${ }^{c}$ to the relation of the natural sciences to agriculture in a fouryear college course. These reports have been of great ralue to the colleges in dereloping their courses in agriculture and reducing them to pedagogic form, and while it has not been found feasible in any single institution to adopt all of the recommendations of the committee, yet many of its suggestions hare been acted upon with henefit to the courses of study in agriculture, so that now these courses are coming to be recognized as coordinate with other university courses in both undergraduate and postgraduate work.

\section{DEPARTMENTS OF ORIGINAL RESEARCH AND GRADUATE STUDY IN AGRICULTURE.}

At the head of the system of agricultural education stand the U'nited States Department of Agriculture and the agricultural experiment stations in the different States and Territorien, organized chiefly as departments of the land-grant colleges. These constitute very largely the university or graduate branch of agricultural education in this country, having for their chief functions the discorery and dissemination of new truths regarding the theory and practice of agriculture. Organized primarily with reference to research, both the Department and the stations to a considerable extent directly promote agricultural

\footnotetext{
a Oftice of Experiment Stations Circular No. 32.

$\checkmark$ Office of Experiment Stations Cireular No. 37.

$c$ Office of Experiment Stations Circulars Nos. 39, 41, and 45.

a Office of Experiment Stations Circular No. 49.

$\epsilon$ Otilice of Experiment Stations Circular No. 55.
} 
education, in the technical sense, by giving instruction to students. This is done by opening their laboratories to assistants who participate in research work while continuing their studies or by imparting new inspiration and knowledge to students who become acquainted with the research work by indirect contact through residence at the institutions where it is being conducted.

The work of the Department of Agriculture along educational lines is rapidly increasing. Not only does it continue to open its laboratories and libraries to officer's of the agricultural colleges and experiment stations who come there to carry on special investigations or to enlarge their knowledge of scientific facts and principles in a special line, but it is doing more than ever before in training the graduates of the agricultural and other colleges who enter the Department as scientific aids. Concerning this feature of the educational work of the Department, the Secretary of Agriculture, in his annual report for 1903, says:

The Department has thus become a postgraduate institution, where groups of sciences are taught and applied. Comparatively little time is devoted to the ascertainment of abstract scientific facts. Every worker is helping somebody, and while doing this he is contributing to what is known relating to the farm and to the education of his associates.

Four hundred and ninety-six students have been admitted to the Department for instruction since 1897 as experts in our several lines of work. Two hundred and forty-nine of these still remain with us, not less than 132 having passed into the classified service, 185 having gone elsewhere to teach, experiment, or demonstrate in private enterprise what they have learned from their teachers, who are our best-equipped scientists in their several specialties.

The Weather Bureau, through its officials at the various stations throughout the country, is taking an active part in public education along meteorological lines. The Bureau of Plant Industry is doing much to aid the school-garden movement by distributing to a large number of schools throughout the country special packages of regetable and flower seeds, together with circulars containing directions for the planting and care of schoul gardens, and by cooperating with other agencies in conducting experimental school gardens.

While the other bureaus of this Department are doing valuable educational work along the lines of research in which they are engaged, the Office of Experiment Stations is the general agency of the Department for the promotion of agricultural edueation throughout the United States and is constantly enlarging the scope and extent of this branch of its work. Special attention is heing given to the better organization of the American system of agrieultural education, so that it may include properly graded courses of instruction, reaching from the graduate school and the college to the common school, and may embrace all the branches of agriculture considered as both a science and an art. Part of this work is being done in cooperation with the Association of American Agricultural Colleges and Experiment Sta- 
tions, the Director of this Office being chairman of the standing committee on methods of teaching agriculture. Its officers and those of the other bureaus of the Department are frequently called upon to address public conventions and other meetings of public men, educators, students, and influential farmers in different States, thus enabling the influence of the Department to be felt in a personal way by the leaders of public opinion in all parts of the country.

Several of the colleges of agriculture maintain regularly constituted graduate schools and not a few other's make arrangements wherehy graduate students are enabled to pursue advanced courses leading to degrees. There are now to colleges which thus provide agricultural work leading to the master's degree and 9 which offer cour'ses in agriculture leading to the doctor's degree.

In the summer of 1902 a graduate school of agriculture was successfully inaugurated at the Ohio State University (Pl. I). The plan for this school was originated by Prof. Thomas F. Hunt, dean of the College of Agriculture and Domestic Science of the Ohio State University, the purpose being to establish a course for advanced students in agriculture at which the leading teacbers and investigators of the leading colleges and experiment stations and this Department should present summaries of the recent progress in agricultural science, illustrate improved methods of teaching agricultural subjects, and afford a somewhat extended opportunity for the discussion of live topics drawn from the rapidly advancing science of agriculture. The board of trustees of the university made provision for its financial support, and the school was successfully conducted during July and Angust. The dean of the school was A. C. True, Director of the Office of Experiment Stations, and the faculty included 35 men, of whom 26 were professor's in agricultural colleges, 7 were leading officers of the Department of Agrieulture, and 2 were officers of the New York State Experiment Station. Serenty-fire students were in attendance, representing 28 States and Territories. The courses of study included agronomy, zootechny, dairying, and breeding of plants and animals. Since 1902 no single college has found it practicable to assume the financial responsibility of conducting such an enterprise, but the Association of American Agricultural Colleges and Experiment Stations has taken up the matter and appointed a committee to derise means for reopening the whool and making it a permanent feature of our system of agricultural education.

\section{AGRICULTURAL COLLEGES.}

There are now in the United States 65 agrieultural colleges, organized under the acts of Congress of July 2, 1862, and August 30, 18?\%. giving Government aid to colleges for the benefit of agriculture and the mechanic arts. In 15 States and 1 Territory separate institutions 


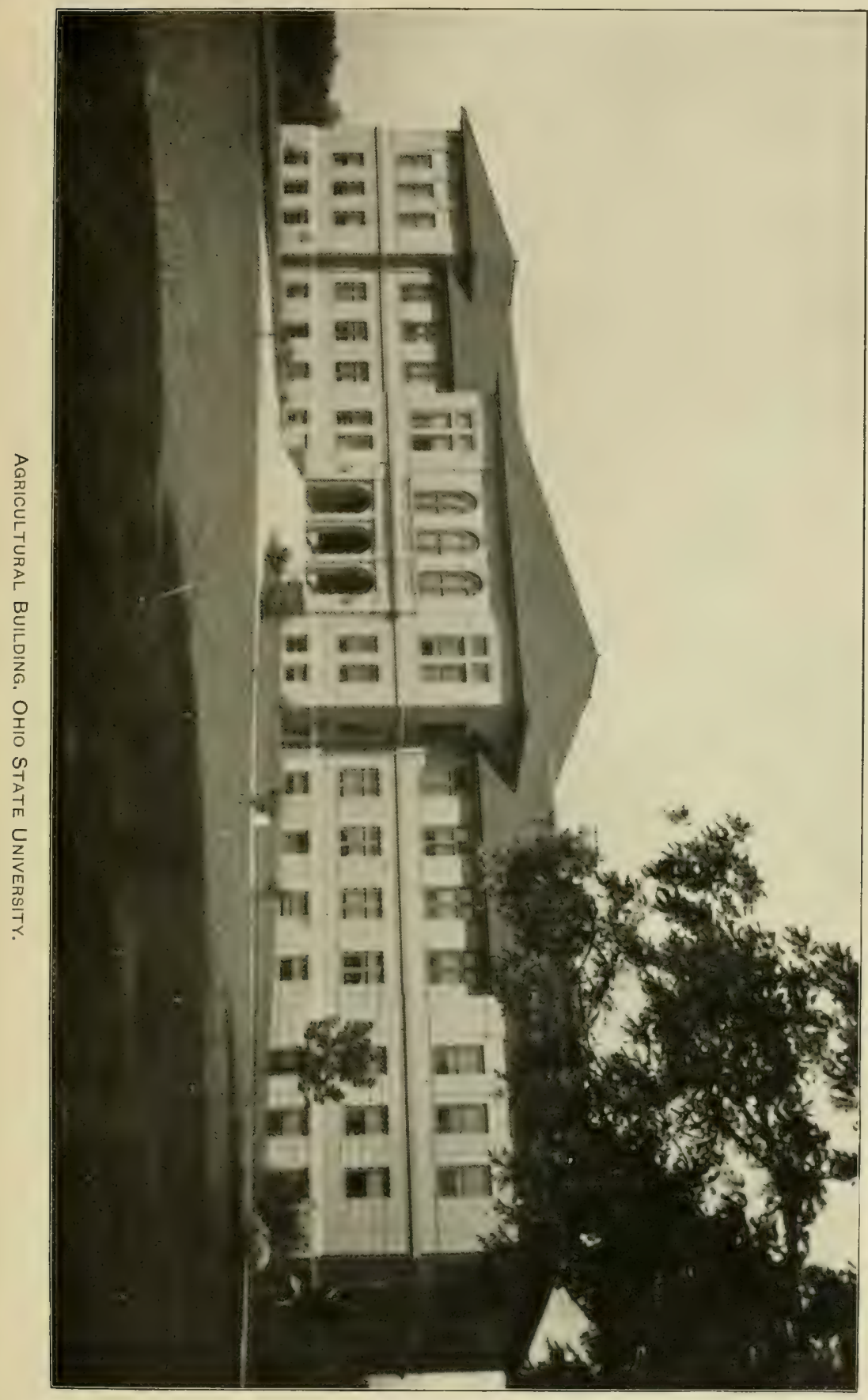



are maintained for white and colored students, and in 15 of these institutions for colored students courses in agriculture are maintained. The colleges of agriculture may be divided into three classes, determined by differences in their organization: (1) Colleges offering only agricultural courses; (2) colleges offering additional courses, especially those in mechanic arts; and (3) colleges of agriculture connected with universities.

The only purely agricultural college in the United States is that in Massachusetts. Agricultural and mechanical colleges are maintained in Alabama, Colorado, Connecticut, Delaware, Iowa, Kansas, Kentucky, Maryland, Michigan, Mississippi, Montana, New Hampshire, New Jersey, New Mexico, North Carolina, North Dakota, Oklahoma, Oregon, Pennsylvania, Rhode Island, South Carolina, South Dakota, Texas, Utah, Virginia, and Washington. Separate institutions of this class for colored students (including departments of universities located apart from the other colleges of those universities) are maintained in Alabama, Arkansas, Delaware, Florida, Georgia, Kentucky, Louisiana, Maryland, Mississippi, Missouri, North Carolina, Oklahoma, South Carolina, Texas, Virginia, and West Virginia. In all of these institutions except that in Arkansas courses in agriculture are conducted, but for the most part the instruction is confined to courses below the college grade. A similar institution, maintained by State and private funds, is the well-known Tuskegee Normal and Industrial Institute, in Alabama.

Colleges of agriculture (or equivalent schools or departments) in universities are maintained, with the aid of national funds, in Arizona, Arkansas, California, Florida, Georgia, Idaho, Illinois, Indiana, Louisiana, Maine, Minnesota, Missouri, Nebraska, Nevada, New York, Ohio, Tennessee, Vermont, West Virginia, Wisconsin, and Wroming. In Massachusetts, Harvard College has a school of agriculture called the Bussey Institution.

Owing to the complicated organization of many of the institutions baving courses in agriculture and the fact that the students in agricultural courses in many subjects are in classes with students in other courses, and that much of the equipment is used in common by the students in all the courses, it is impracticable to show hy statistics, with exactness, the means and facilities for strictly agricultural educaltion. The general statistics of the land-grant institutions may, however, serve to show with how great an enterprise, devoted chiefly to higher education along scientific and industrial lines, agriculture has been joined in permanent alliance, and to indicate in some measure how extensive are the educational facilities at the command of the youth of the country who have sufficient intelligence, courage, and perseverance to follow out long and thorough courses of study in agriculture. 
Educational institutions receiring the benefits of the acts of Congress of July 2, 1862, and August 30, 1890, are now in operation in all the States and Territories except Alaska, Hawaii, and Porto Rico. The total number of these institutions is 65 , of which 63 maintain courses of instruction in agriculture. The aggregate ralue of the permanent funds and equipment of the land-grant colleges and universities in 1903 is estimated to be as follows: Land-grant fund of $1862, \$ 11,140, \$ 90.51$; other land-grant funds, $\$ 2,8+9,293.49$; other permanent funds, $\$ 14,926,747.49$; land grant of $18: 2$ still unsold, $\$ 1,292,-$ 460.26 ; farms and grounds owned hy the institutions, $\$ 5,610,41.03$; buildings, $\$ 21,246,159.88$; apparatus, $\$ 2,379,742.28$; machinery, $\$ 1,-$ $112,805.28$; libraries, $\$ 2,114,802.60$; live stock, $\$ 252,490.66$; miscellaneous equipment, $\$ 3,852,629.77$; total, $\$ 69,778, \pm 63.25$. The income of these institutions in 1903 , exclusive of the funds received from the United States for agricultural experiment stations $(\$ 119,999.50)$, was as follows: Interest on land grant of $1862, \$ 67 t, 174.77$; interest on other land grants, $\$ 84,903.31$; Lnited States appropriation under act of $1890, \$ 1,200,000$; interest on endowment or regular appropriation, $\$ 278,409.25$; State appropriation for eurrent expenses, $\$ 2,469,8+8.4$; State appropriation for buildings or other special purposes, $\$ 1,5 \pi$, , 927.40; endowment, other than Federal or State grants, $\$ 602,802.41$; tuition fees, $\$ 944,826.07$; incidental fees, $\$ 294,492.95$; miscellaneous, $\$ 1,120,993.80$; total, $\$ 9,24,378.40$. The value of the additions to the permanent endowment and equipment of these institutions in 1903 is estimated as follow: Permanent endowment, $\$ 626,916.56$; buildings, $\$ 1,426,330.31$; libraries. $\$ 135,312.46$; apparatus, $\$ 104,247.94$; machinery, \$169,182.24; live stock, \$51,140.96; miscellaneous, \$230.552.91; total, $\$ 2,743,683.38$.

The number of persons in the faculties of the colleges of agriculture and mechanic arts was as follows: For preparatory classes, 445 ; for collegiate and special classes, 2, (1)2t; total (deducting 8 counted twice), 2, 461 . In the other departments the faculties aggregate 1.1+1, making: a grand total of $3,60: 2$ persons in the faculties of the land-grant institutions. The students in 1903 were as follows: (1) By classes-Preparatory, 8,801; collegiate, 19,161; short course or special, 7,999; post-graduate, 605 ; other departments, 16.760); total (counting none twice), 52.48\%. (2) By courses: Fonr-yeur-Agriculture, 3,146; horticulture, 53:!; household economy, 873 ; mechanieal engineering, 4,475 ; civil engineering, 2,587; electrical engineering. ‥116; mining engineering. 955; chemieal engineering, 188; architecture, 15:. ShorterAgriculture, 5,505; dairying, 867 ; horticulture, $36 \overline{7}$; veterinary science, 811 ; military tacties, 16,316 . The graduates in 1903 were $4,52 t$, and since the organization of these institutions, 53,252. The arerage age of graduates in 1903 was 21 years and 10 months. The total num- 
ber of volumes in the libraries was $1,83 \bar{\tau}, 461$. The total number of acres of land granted to the States under the act of 1862 was $10,170,851$, of which $1,007,994$ are still unsold.

\section{THE FOUR-YEAR COLLEGE COURSES.}

In nearly all of these institutions the college course in agriculture extends orer four or more years. In cases where more than four years are required, an additional year or two years has been added to prepare students for admission to the regular course. The course varies considerably in different institutions as regards the requirements both for admission and for graduation. In some cases students are admitted directly from the common schools, while in others the entrance requirements are on a level with those for admission to other college courses in high-grade colleges. Gradually, however, a number of the institutions which formerly admitted students from the common schools are raising their entrance requirements to correspond more nearly with the recommendations of the committee on entrance requirements of the Association of American Agricultural Colleges and Experiment Stations.

The course at the Massachusetts Agricultural College may be considered typical of relatively high-grade college courses in agriculture as given in Ameriean colleges. Candidates for admission must be at least 16 years old, and are required to pass examinations in English, general history, physiology, physical geography, algebra (through quadratics), plane geometry, and civil govermment. The student is required to follow a definitely prescribed curriculum during two years, after which he is allowed to elect one of the following courses: Agriculture, horticulture, biology, chemistry, mathematics, and landscape gardening. In freshman year the following subjects are included in the course: Agriculture, botany, chemistry, algehra, geometry, trigonometry, English, French, military tactics, and history; in sophomore year, agriculture, horticulture, zoology, chemistry, English, and German; in junior year the student follows one of the prescribed courses mentioned above; and in senior year, together with the required military science, bacteriology and Constitution of the United States, he must take at least three elective studies closely correlated with his junior-year course, which may be selected from the following: Agriculture, botany, horticulture, landscape gardening, chemistry, physics, entomology, veterinary science, engineering, English, French. German, Latin.

A similar arrangement prevails at the Michigan Agricultural College, where the agricultural students, after pursuing the prescribed course for two years, are allowed to elect between agriculture, horticulture, and forestry. Iowa State College now offers four full four- 
year courses in agriculture in which the student is allowed to specialize in agronomy, dairying, animal husbandry, or horticulture.

The elective system is gaining ground in all the agricultural colleges, and especially is this true of those comnected with the universities. The University of Illinois (Pl. II), for example, offers 18 electives in the department of agronomy, 20 in the department of animal husbandry, and 22 in the department of horticulture, besides special courses outlined for graduates. In the reorganized course of study of the College of Agriculture of Cornell University students are allowed to elect most of the work of the last two years in the regular college course. For this purpose 8 groups of electives are prorided as follows: (1) Thesis, (2) chemistry and soil, (3) plant production, (4) animal hushandry, (5) mechanics and engineering, (6) farm home, (7) rural economy, (8) outdoor art.

Another tendency of these larger institutions is worthy of notice in this connection, namely, that of dividing the subject of agrieulture into specialties, such as plant industry (including agronomy, horticulture, and forestry), animal industry, agrotechny (dairying, sugar making, etc.), rural engineering, and rural economy. This specialization has resulted in the organization of agricultural faculties with professor's of agronomy, horticulture, animal industry, ete., instead of, as in former years, one professor charged with teaching the whole subject of agriculture and also, not infrequently, such related subjects as agricultural ehemistry, botany, and veterinary seience.

Much greater attention than formerly is heing given to the improvement of methods of teaching agricultural subjects. This is evidenced by the employment of more thoroughly traned teachers, by individual and associated efforts to define and arrange the topics of instruction in accordance with pedagogical principles, by the general adoption of the lahoratory sytem as applied to the field, the plant house, and the harn, as well as to the buildings constructed with special reference to the peculiar needs of instruction in agricultural subjects.

The collection and devising of apparatus and illustrative material are being pushed with much enthusiasm and success. Wherever means will permit, and in an increasing number of institutions, the housing and equipment of the agricultural department will compare favorably with that of other departments (Pls. III and IV). Along with the improvement of the college courses m anriculture has come the realization of the true function of these courses. It is now well understood that they are for the training of the leaders in agricultural progress, and not for the general education of the agricultural masses. For this purpose they are to be made as thorough and complete internally and externally as the manifold needs of American agriculture for well-trained and intelligent leadership may require. Their suceess is to be judged by the same standard that is applied to other college courses. and the number of students is not of so much importance ats 


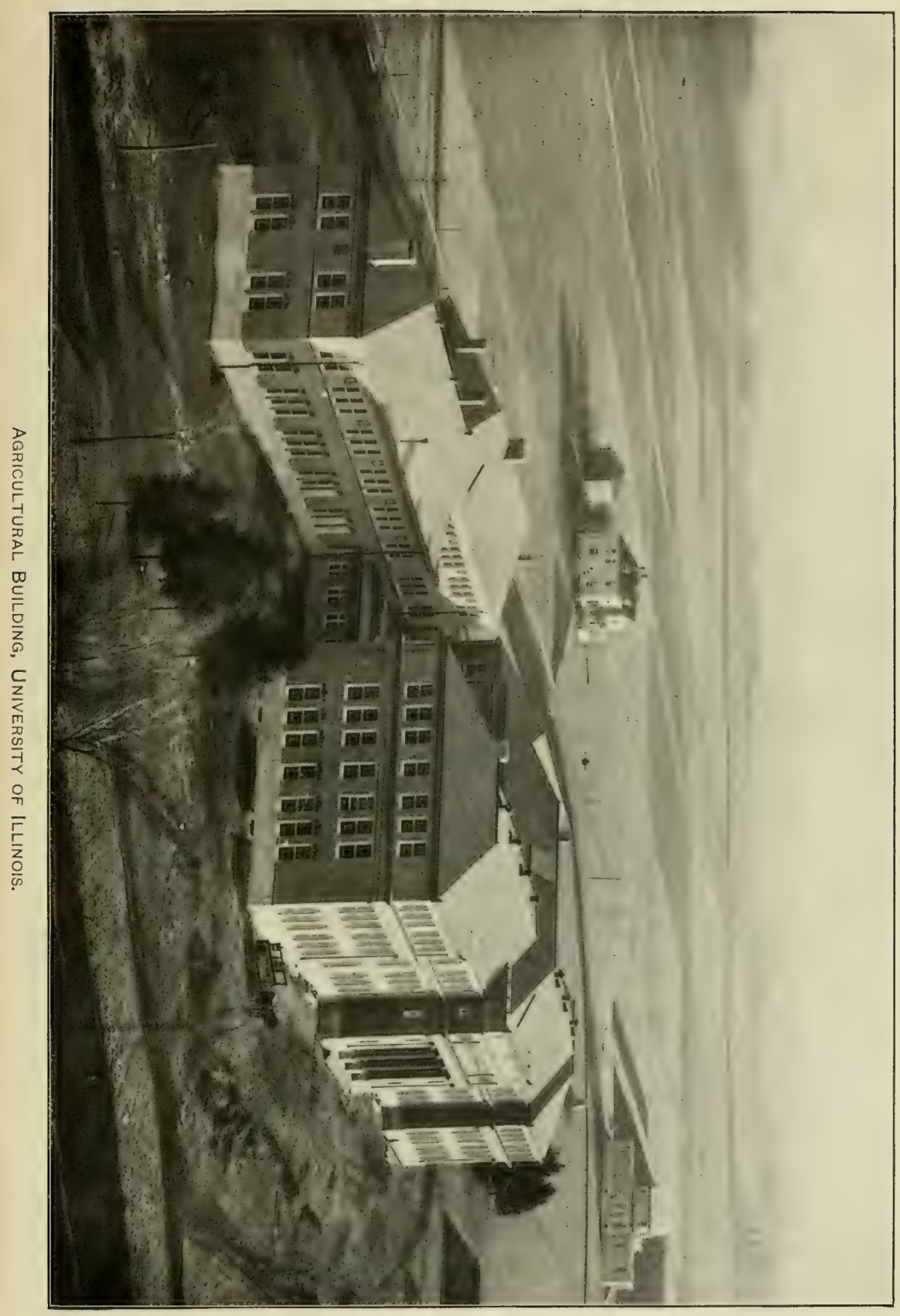





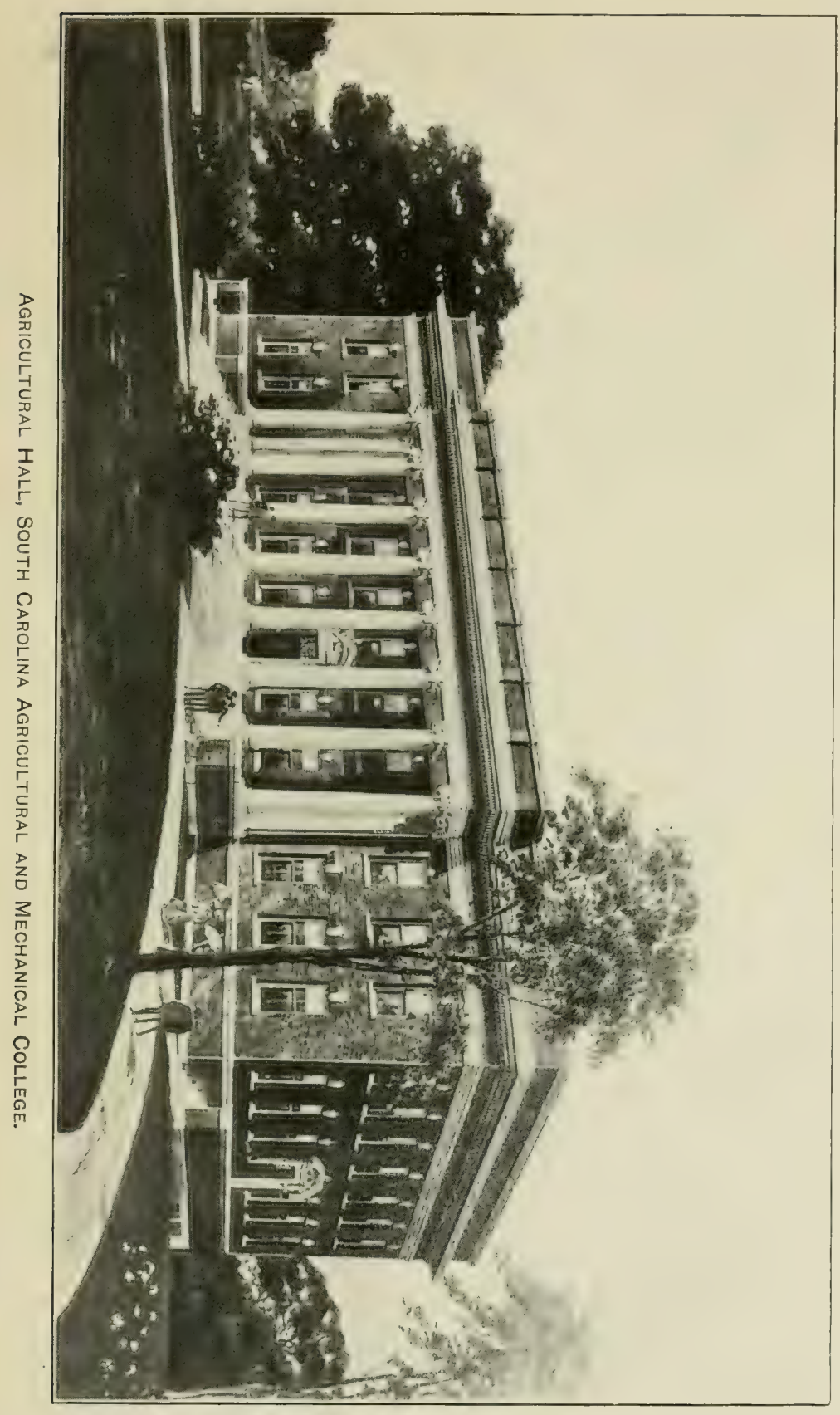





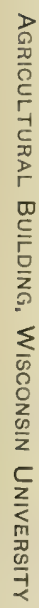

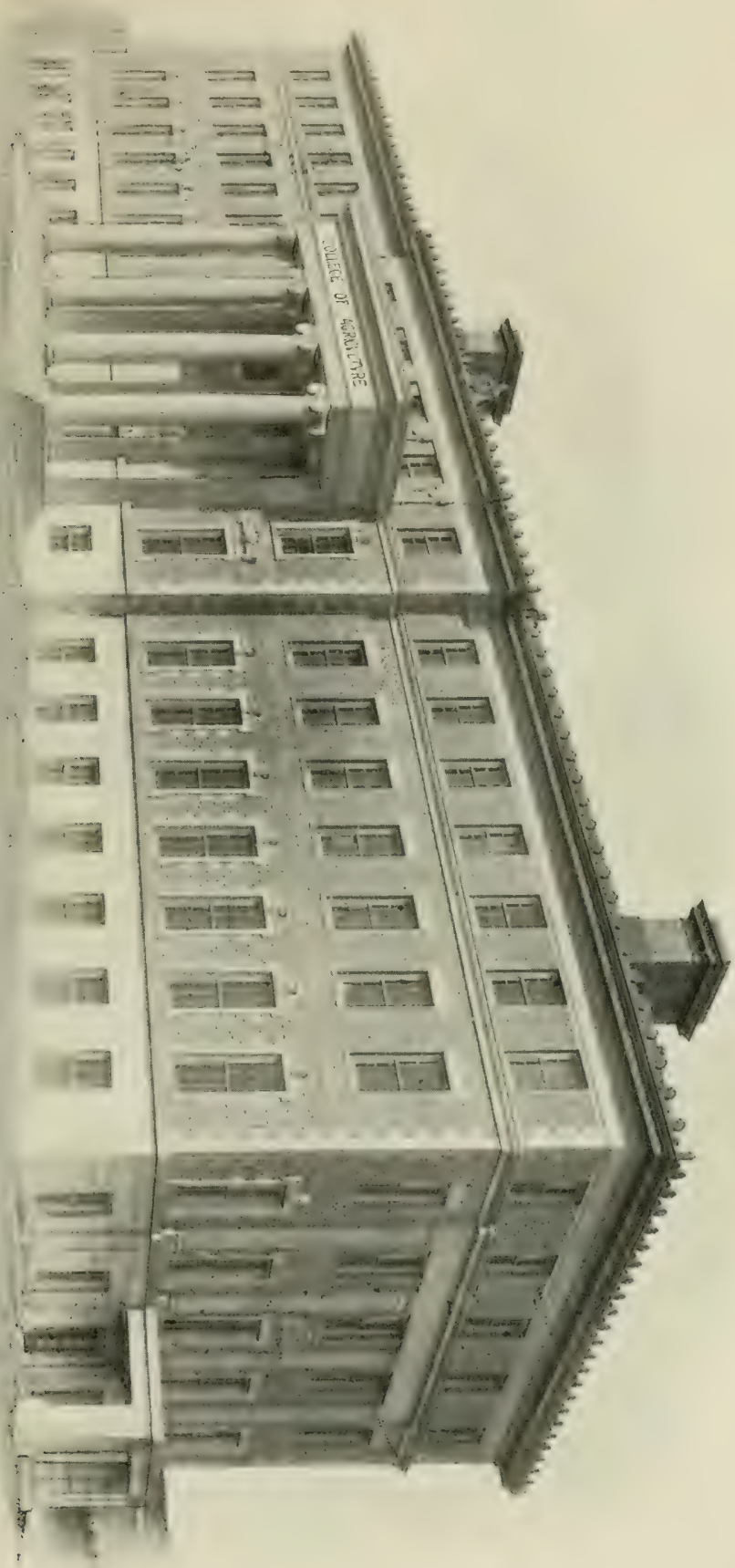



their quality. For the general education of the agricultural people, young and old, other agencies than the four-year college course are to be employed, which will require for their management a large share of the graduates of the agricultural colleges.

\section{THE SHORT AND SPECIAL COURSES.}

In the effort to meet the needs of the various classes of students, especially of those who are unable to complete a full college course, the agricultural colleges have been unusually active in recent year's in organizing short and special courses of different kinds. Forty-four of these institutions have organized such courses, which are planned to meet the needs of young people who may be classitied somewhat roughly as follows: (1) Those preparing to enter a four-year agricultural course; (2) those desiring instruction in agrieultural subjects, but having insufficient scholastic attainments to carry the full collegiate course; (3) those unable to leare home for an extended course, who desire instruction in some particular phase of agricultural science or wish to become proficient in some branch of agricultural practice, and (t) teachers desiring to prepare themselves to give instruction in nature study and elementary agriculture. The general features of these courses are shown in the following excerpt from the introduction to a recent bulletin of the Office of Experiment Stations: $a$

For students preparing to enter a four-year agricultural course, high-school agricultural courses two or three years in length have been organized; also in some instancey one-year or two-year preparatory courses. These high-school courses also serve many more students as finishing courses-preparation for life work. This is the purpose served alsu by the so-called practical one-year and two-year agricultural courses organizerl for those of limiter scholastic attainment-courses having a minimum of culture studies and pure science and a maximum of apylied seience. Thirty colleges now offer courses falling under one of these two classes, and all but nine of these courses are more than one year in length.

Great importance attaches to courses of this nature, and great care should be exercised in planning them, because it is the graluates of these courves more than the graduates of the four-year courses who go back to the farms. It will be said, and it is true, that the best and most thorough course of study is none too good for the farmer; that a man should be as well trained for the profession of farming as for the law or medicine. But it must be remembered that there were well-defined courses of sturly in law and medicine long centuries before the farmer was considered worthy of instruction. In these professions there is now a great body of trained men and specialists from whose ranks special positions may be fillerl, while in agriculture the men of scientific attainments are comparatively so few and the demand for them in college, station, and other attractive and remunerative positions is so great that few bachelor-dexree men feel that they can afford to go back to the farm. For the present, then, and for some years to come, the college of agriculture will have an important mission to perform through its secondary and short courses in the training of young men for the practice of agriculture.

For those actually engaged in agricultural occupations-the farmers, dairymen, and fruit growers, and their sons and laughters who are unable to leave home during the busy seasons-the special winter courses have been organized. These courses 
vary in length from a week or ten days to ten or twelve weeks. They are in most cases severely practical. They center around the judging parilion, the laboratory, the dairy, and the cheese room, with lectures and readings to supplement the practicums. The nature of these courses is even more varied than their length of term. Twenty-two colleges offer courses in general agriculture, including more or less thorough instruction in plant production, animal hushandry, dairying, poultry culture, ete.; 19 offer courses in general dairying, 3 in creamery management, 2 in farm dairying, 2 in cheese making, 5 in animal husbandry, 9 in horticulture, 4 in poultry culture, 3 in domestic science, with more or less of horticulture, floriculture, and like subjects adapted to the needs of young women, and 1 each in agronomy, bee culture, forestry, beet-sugar production, farm mechanics, correspondence courses, hotany, bacteriology, and entomology. Two colleges offer courses designated agriculture and horticulture; two, courses designated agriculture and dairying, and one a course in agriculture, horticulture, and mechanic arts. Most if not all of these courses include instruction in a number of subjects not indicated in the names of the courses. There are also a large number of practicum courses and lecture courses which are confined to a single line of practice, such as cereal jurlging, stock judging, and the destruction of noxious insects. Six colleges offer a total of $4+$ such courses.

The special winter courses are the utility courses, important because of their influence on the present-day agricultural practice and because of the influence of present practice on future practice. And present practice is sure to have a powerful influence on the young people who are to be the future farmers and on the quality of soil, farm machinery, and domestic animals with which these young people will have to do when they take charge of the farms. The special winter courses, then, are an important and legitimate feature of agricultural instruction, capable of giving a strong uplift to present agricultural conditions.

And, finally, there are the summer schools for teachers and the one-year and twoyear normal courses, in all of which nature study anil elementary agriculture are important features. It least 8 colleges have organized courses of this kind, and have fouml teachers prompt and eager to take advantage of the opportunities thus afforded them for preparing to bring the children committed to their charge into more intimate and sympathetic relations with their natural environment. Some of the States now require that instruction in the elements of agriculture be given in the public schools, and the agricultural colleges in those States are aiding to prepare the teachers for this work. More work of this kind needs to be done in order that country children may learn to know and appreciate the beauties and advantages of rural life, and that city children may be enabled to make use of their more limited opportunities for the employment of trees, shrubs, flowers, and other nature material in making the city more wholesome and beautiful, and may have their attention turned to the advantages and opportunities of rural life.

Schools of agriculture as mentioned above or high-school courses in agricultural colleges are now maintained in Maine, Minnesota, Nebraska, Oklahoma, Rhode Island, and Washington.

The nature and extent of the special courses now offered hy a large number of the colleges are shown hy the following description of typical courses:

\section{AGRONOMY.}

The winter comse in agronomy of the college of agriculture of the University of Missouri continues eight weeks and includes instruction in the following subjects:

Farm equipment, including implements, machinery. and buildings. 
Soils, their origin, formation, distribution, chemical and physical properties, and classifications.

Fertilizers and manures, relative values, preservation, and application.

Farm crops, conditions of germination and growth, rotation, cultiration, harresting, storing, and varieties.

Horticulture. propagation by grafting, budding, layering, etc.; soils; location and care of orchards; fungus diseases and their treatment; picking, packing, storing, and marketing of fruits, and the planting of home grounds.

Botany, with special reference to the structure, use, and functions of plants of economic importance.

Economic entomology, agricultural chemistry, and carpentry and blacksmithing.

\section{DAIRYING.}

The winter dairy course given in the college of agriculture of the Lniversity of Wisconsin is typical of these courses. It is a twelve weeks' course and includes the following:

Twenty lectures on milk, its constituents, testing, creaming, and churning, and principles of cheese making.

Creamery management and dairy bookkeeping.

The theory and art of cheese making.

Sixteen lectures on the relation of bacteria to dairy problems.

Fifteen lectures and demonstrations on the care and management of boilers and engines.

Eight lectures on feeds and feeding.

Eight lectures on heating, ventilation, and drainage.

Eight lectures on the breeding and selection of dairy cows.

Ten exercises on preliminary practice.

In addition, practical work is given in the creamery, the pasteurizing and testing rooms, the cheese rooms, and the machinery and power room.

\section{ANIMAL HUSBANDRY.}

The animal husbandry short course of the school of agriculture of Purdue University extends over ten weeks and includes the following subjects:

Lectures and practice in judging beef and dairy cattle, swine, sheep, and horses, two hundred and thirty hours.

Live-stock management, twenty hours.

Care of farm animals, twenty lectures and ten two-hour clinics. Examination of horses for soundness, ten lectures and ten clinics. Agricultural physics, twenty three-hour periods.

Soils, manures, and crops, thirty hours. 
Farm buildings (lectures and practice in drawing plans), ten three hour periods.

Forage crops, twenty hours.

Chemistry of soils, manures, and fertilizers, twenty hours.

\section{UNIVERSITY EXTENSION IN AGRICULTURE.}

Under the title "Universitr extension" are included all of the efforts of a university or a college to carry instruction to the people outside the limits of its orvn campus. Though not always spoken of under this head, no university-extension movement in this country ha: actually been so widespread as that on behalf of agriculture. Broadly speaking, this would properly include the dissemination of agricul. tural information through the publications of the experiment stationand this Department, of which about 12,000,000 copies are issued annually. But confining ourselves to what is usually considered the more legitimate field of university extension, we find many of the colleges now extending their educational influences orer wide areaand among many hundreds of people not enrolled in their regular courses through the agency of farmer's' institutes, reading courses for farmers and farmers' wires, correspondence courses, agricultura experimental unions, and the introduction of nature study and school garden work with children. The farmer's' institutes, which are now held in 46 States and Territories, are attended by over 900,000 people

A number of the colleges maintain reading courses for farmers, in which certain lines of reading are regularly taken up, review question: are sent out, and the answers received are criticized. Some of the colleges modify this procedure by preparing special publications for the members of its reading courses to study. Reading courses are now conducted under the auspices of the agricultural colleges in Michigan, New York, South Dakota, and West Virginia. Closely related to the reading courses are the correspondence courses conducted by the Pennsplvania State College, which enrolls several hun dred correspondents who regularly receire mimeograph copies of lessons prepared under the direction of the professor of agriculture in the college, and similar courses in agriculture and horticulture now offered by the L'nirersity of Wyoming. The success of exten sion work of this kind has led to the estallishment recently of three quite strong correspondence schools under private auspices, two of which offer courses in agriculture and the other courses in poultry culture.

Experimental unions which are organizations of college graduates and nongraduate students for the purpose of extending the influence of the colleges and experiment stations by means of cooperative experiments with field crops, methods of culture, fertilizers, etce, are now organized in Illinois, Iowa, Ohio, New York, Wisconsin, and pośsibly one or two other States. 


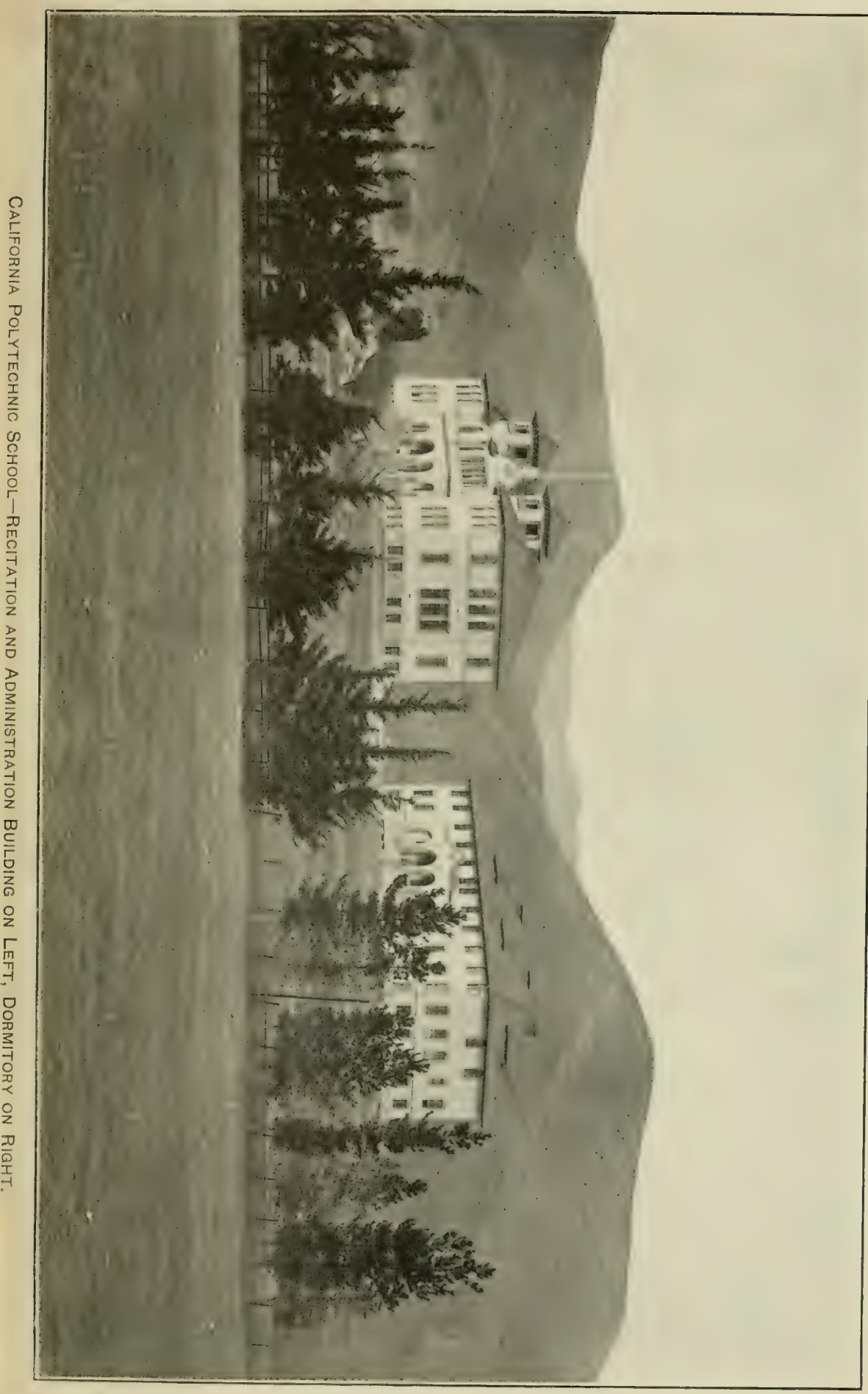



Sereral of the agricultural colleges are further extending their influence through the preparation of nature-study leaflets and schoolgarden leaflets and through lectures and correspondence on the part of their officers to promote a better understanding of the elements which make up the environment of children in rural sections, the aim heing, first, to put children into better sympathy with their surroundings, and, secondly, to prepare the way for instruction in the elements of agriculture in the rural schools.

\section{SECONDARY AGRICULTURAL SCHOOLS.}

Besides the high school agricultural courses and schools of agriculture mentioned above as maintained in connection with colleges of agriculture, there is a considerahle number of secondary agricultural schools, some of which are supported by State or local funds and some by private funds.

Alabama has nine agricultural schools, one in each Congressional district, supported by State and local funds. These are located at Abbeville, Albertville, Athens, Blountsville, Evergreen, Hamilton, Jackson, Sylacauga, and Wetumpka. Ustally these schools are connected with local public schools and resident pupils predominate, but there are also quite a number of pupils enrolled from the towns adjoining each school.

The California Polytechnic School, located at San Luis Obispo, was opened October 1, 1903. This is a State institution estathlished under an act of the legislature of March s, 1901, to take effect January 1 , 1902, " " to furnish to young people of hoth sexes mental and manual training in the arts and sciences, including agriculture, mechanics, engineering, business methods, domestic economy, and such other branches as will fit the students for the nonprofessional walks of life."

On making a careful survey of the educational institutions of the State the trustees found that the greatest need was for a secondary school, giving hoys and girls "a training in the arts and sciences which deal peculiarly with country life-the life of the home, the farm, the orchard, the dairy, and the shop." Agriculture, domestic science, and mechanies were therefore made the main lines of instruction in this school. A farm of 280 acres was purchased, and on this two large buildings have been erected (PI. V). These are a recitation and administration building \pm 7 by 100 feet and a dormitory 40 by 100 feet.

Students are admitted at the age of 15 year's and must have had previous training equivalent to the usual grammar school course. The course of study covers a period of three years. The cost of books, supplies, and laboratory fees will be $\$ 35$ a year, and of room and board $\$ 20$ or $\$ 25$ per month. The school is under the manage$31032-04-2$ 
ment of a hoard of trustees, including the governor and superintendent of public instruction ex oflicio. Dr. Leroy Anderson is at the hear of the faculty, with the title of director.

An agricultural school of secondary grade has recently been opened at Rutherford, Napa County, Cal., under the auspices of the Touths' Directory of San Francisco, a Roman Catholic organization. For a number of years this organization has been sending boys who had graduated from the grammar grades of its city school to Janches in different parts of the state, but with unsatisfactory results. A ranch of 1.600 areres has therefore been purehased, on which rineyards and orchards are being planted and stock raising and dairying are heing established with the aid of the students sent from the city schools. A building with class rooms, laboratories, and dormitories to aceommodate 150 boys is now being erected.

In Connecticut there is a school of horticulture located just outside the city limits of Hartford and supported by private funds. The equipment of the school consists of a laboratory and lecture huilding, with attached workroom and greenhouse, a stable, and gardens covering several acres. The school is maintained primarily for the purpose of affording instruction in horticulture and gardening to the pupils of the public schools in Hartford. The laboratory method of instruction is followed and atch student is provided with a garden, for which he is responsible. Such instruction as is necessary for an understanding of the work in the greenhouse and the field is given by means of lectures. During the season of 19112 instruction was given to about $9(0)$ persons. including 1 is gardeners and a large number who took only nature-study work in comnection with city vacation schools.

The first ammual report of the Winona Agricultural and Technical Institute, at Winona Lake, Ind., founded in 1902, shows that (12 boys were enrolled during its first session, of whom 55 came from the city, 21 from villages, and 14 from farms, and lamged in age from $1 t$ to 22.2 . This is a secondary school, having a two-year preparatory department corresponding to the serenth and eighth grades of the public schools, and a four-year academic department providing four groups of studies, entitled agriculture, trades, elementary technology, and academice Instruction in agrieulture begins in the second year of the preparatory department and runs through the four years of the academic department. The institute is provided with a small farm, two dormitory buildings, and a substantial brick lahoratory building known as the Mount Memorial Building. The school is supported hy private funds.

In Maswachusetts an agricultural department has been established in connection with the Mount Hermon school, near Northfield, founded by the late I). I. Moody. For a number of years this school has hat a farm of about $1(x)$ acces, with a dairy of $2(x)$ cows, and fruit orehards, gardens, and a cannery. There was, howerer, no theoretical instrue- 
tion in agriculture or horticulture until the autumn of 1903 , when $\mathrm{Mr}$. Harry Hayward, of the U.S. Department of Agriculture, was called to the school to organize departments of instruction in agriculture, horticulture, and dairying.

This State also includes a number of institutions offering courses in horticulture for women. At Groton there is the school of Horticulture and Landscape Gardening for women conducted under private auspices. Simmons College, Boston, now provides a course in theoretical and practical horticulture for women. The course will extend over three or four years, the first two years to be spent in Boston studying the principles of horticulture, and the remainder of the time at the Massachusetts Agricultural College. Wellesley College also announces a course in elementary horticulture and landscape gardening, to include lectures on the preparation of soils, the propagation, cultivation, and pruning of plants, school gardens, and planting designs. This course covers one year with three hours a week.

In Missouri the three State normal schools, located at Cape Girardeau, Kirksrille, and Warrenshurg, give instruction in agriculture for the purpose of preparing teachers to introduce this subject into the public schools of the State.

The Baron de Hirsch Agricultural and Industrial School, at Wroodbine, N. J., regularly opened for students in $18: 4$, provides general and agricultural education of the secondary grade, combined with a large amount of practical farming and horticulture, for a limited number of boys and girls.

In Elyria, Ohio, a city of about 10,000 inhabitants, an agricultural college graduate is employed to teach agriculture and chemistry in the puhlic high school, and an elective course has been arranged in which agriculture is taught in the third and fourth years. This will include instruction in animal hushandry with especial reference to dairying and soils and farm crops.

The National Farm School, located at Doylestown, Pa., was established in 1896, and provides secondary instruction in agriculture with practical farm work for about to boys. The equipment of the sehool includes a farm of 122 acres, a stone main building, a chemical laboratory, a dairy building, greenhouses, a residence for the dean, barns, and other farm buildings, and live stock. The school is supported by a small State appropriation, private donations, fees, and sales of firm products. Dr. J. H. Washburn, formerly president of Rhode Island College of Agriculture and Mechanic Arts, is dean of the school.

Irisconsin has two county agricultural schools established under the provisions of a State law granting aid not to exceed se, ,o(t) per annum to the two counties which first recet buildings and provide other necessary equipment for such schools.

The Marathon County School of Agrieulture and Domestic Economy, 
located at Wausan, was opened Octoher 6, 1902. The buildings and equipment provided for this sehool cost \$20,000) (Pl. VI, fig. 1). The school grounds cover 6 acres. The course of study for boys includes soils, plants, animal husbandry, rural arehitecture, blacksmithing, carpentry, and mechanical drawing. The course of study for girls inchudes cookirg, laundering, sewing, floriculture, and home management and decoration. Both courses include English language and literature, U'nited States history, civil government, and commercial arithmetic with farm accounts. Tuition is free to students living in Marathon County. The cost of hoard and rooms runs from \$2.50 to \$3. The principal of the school is R. B. Johns, a graduate of the University of Wisconsin.

The Dunn County School of Agriculture and Domestic Science, located at Menomonie, was opened Octoher 20, 1902. It is equipped with a tine brick main building erected by the county at an expense of $\$ 6,000$ (Pl. VI, fig. 2), and a frame building for shopwork which, with the grounds surrounding the school, cost $\$ 5,000$. The courses of study are very similar to those in the Marathon School and require two year's for completion. The principal of the school is Dr. K. C. Daris, a graduate of the Kansas Agricultural College.

The Girls' Industrial College at Denton, Tex., was opened to students in September, 190\%. Considerable attention will be given to the teaching of horticulture and ornamental gardening, and the courses will also include instruction in floriculture, dairying, bee keeping, and poultry keeping. Three new greenhouses, 18 by t) feet, have been completed, and a small nursery has been established. A campus of about to acres will be deroted to landscape gardening and forestry.

\section{PRIMARY SCHOOLS.}

The introduction of the teaching of agrieultural subjects in the primary schools is being widely discussed at the meetings of teachers and farmers. A few schools of primary and grammar grades have attempted. with apparent sucess, to give instruction in the elements of agrieulture. The Watkinson Farm School, near I Iartford, Conn., and the Thompsons Island Farm school, in Boston Harhor, are examples of such institutions. Near Knoxville, Temn., plans have been made and land purchased for the establishment of a central rural school in which the pupils will receire instruction, not only in the usual subjects taught in such a school, hut also in agricultural subjects, such as planting and cultivating fruits and flowers, rasing poultry, and operating dairies. In Missouri and portions of Illinois numerous successful experiments along these lines have been made in the rural schools (Pl. V'Il, fig. 1), while in other states the public schools of both urban and rural districts have made encouraging progress in the 


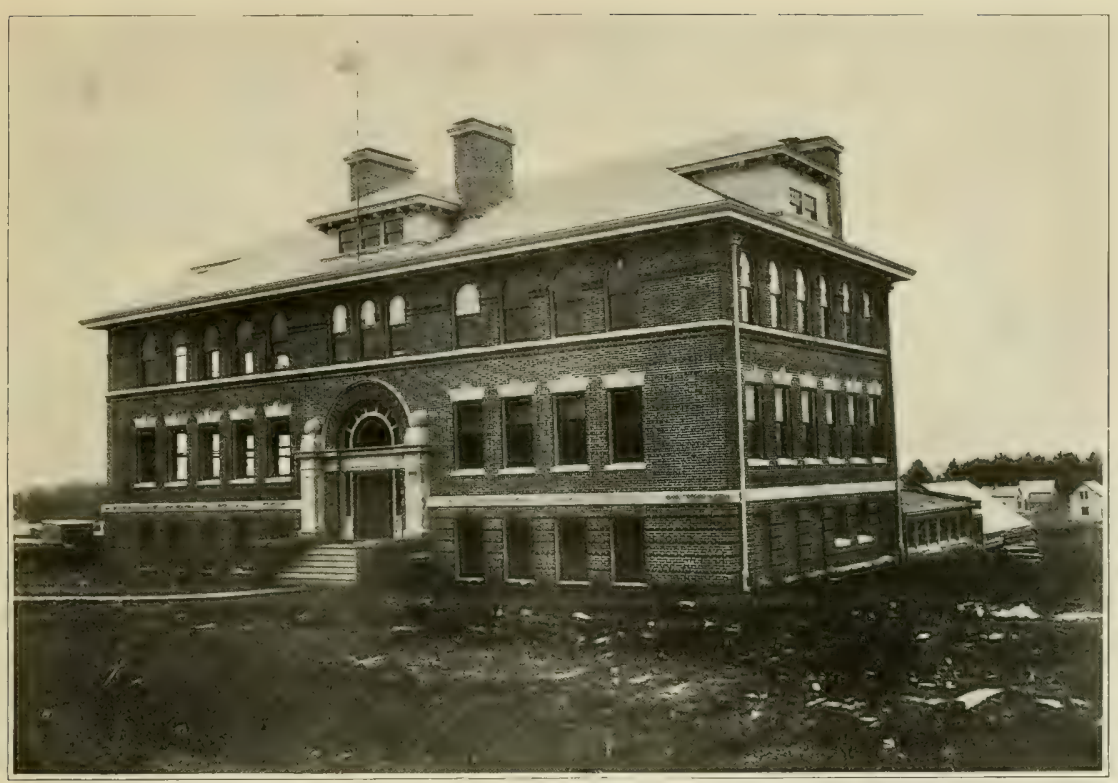

Fig. 1.-Main Building, Marathon County School of Agriculture and Domestic ECONOMY.

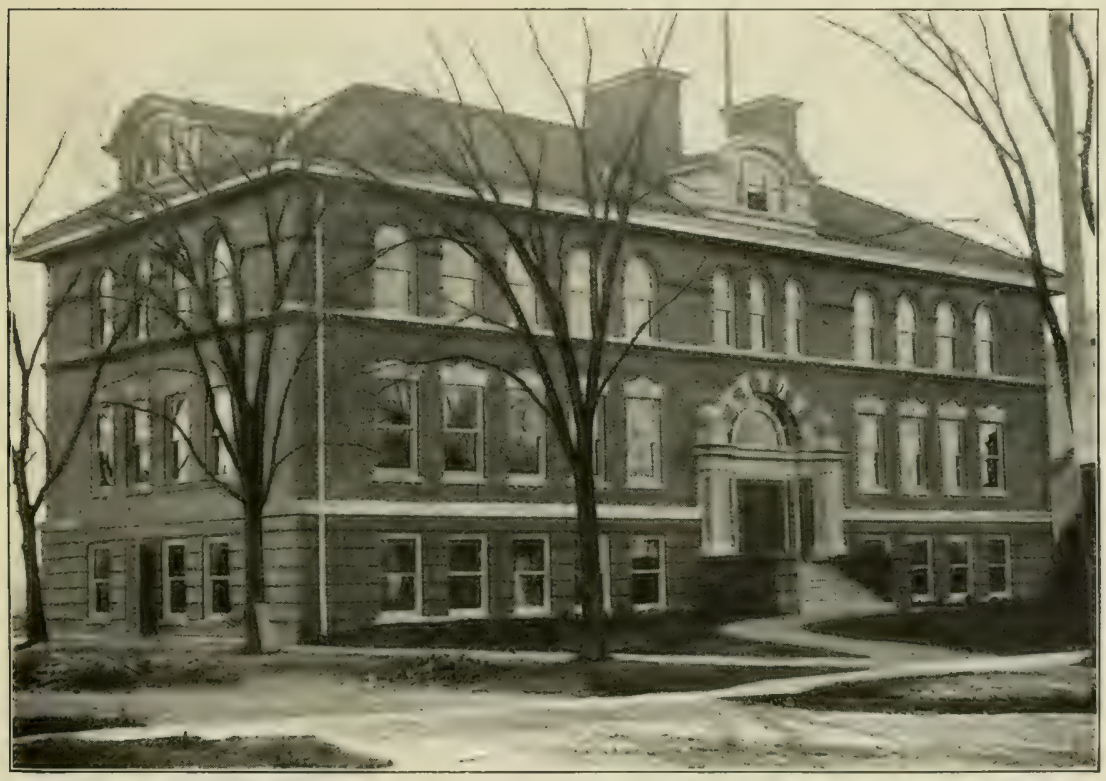

Fig. 2.-MAin Building, Dunn County School of Agriculture and Domestic ECONOMY. 



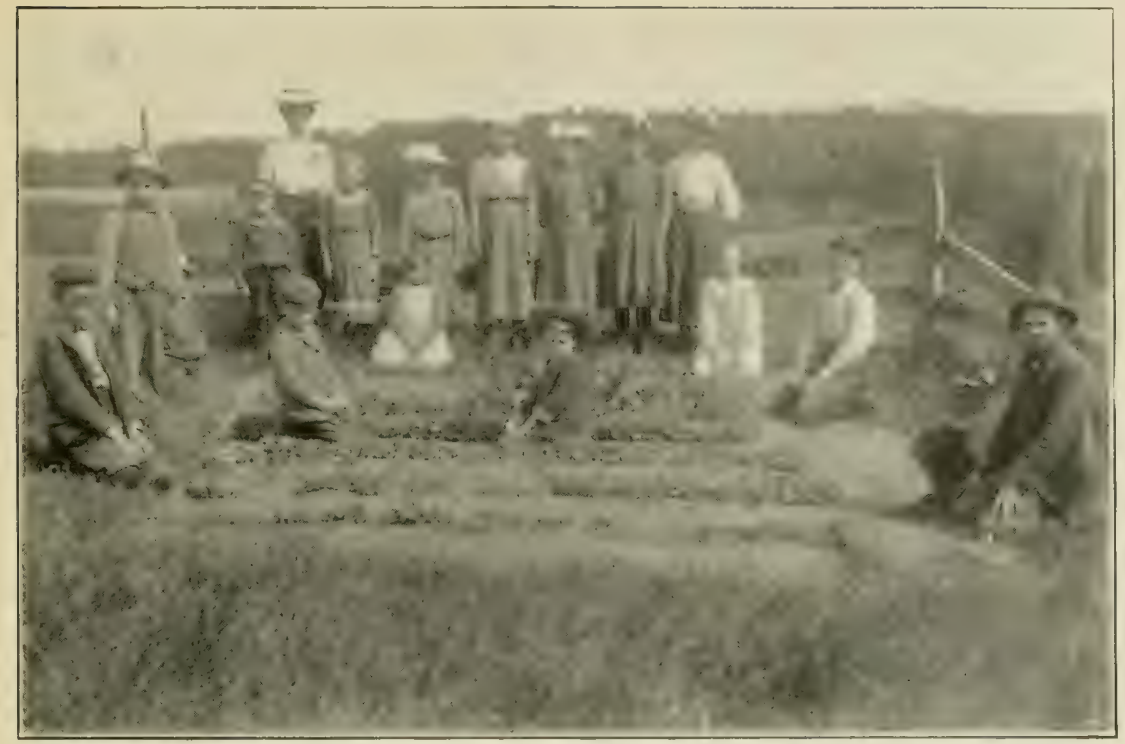

Fig. 1.-A Country School Garden, District 58, Winnebago County, ILL.

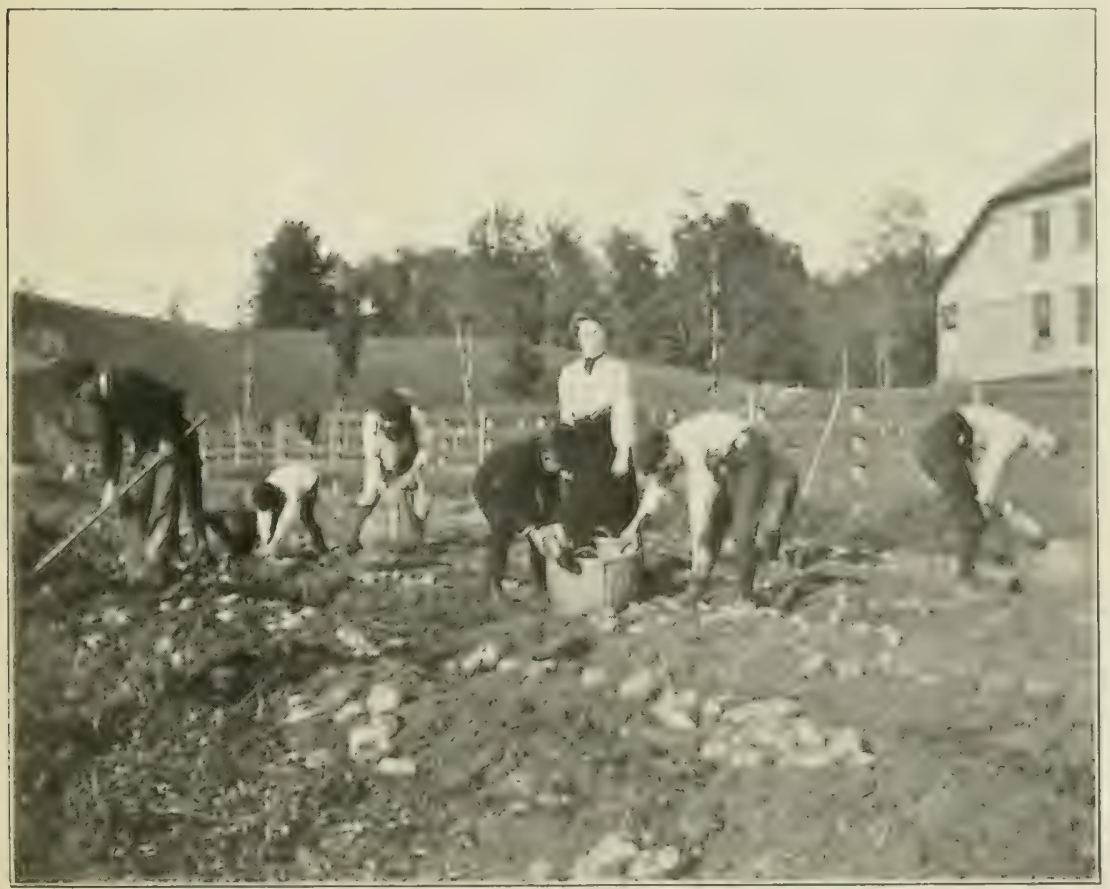

Fig. 2.-Potatoes Raised by pupils in the Practice school of Vermont state NORMAL SCHOOL. 



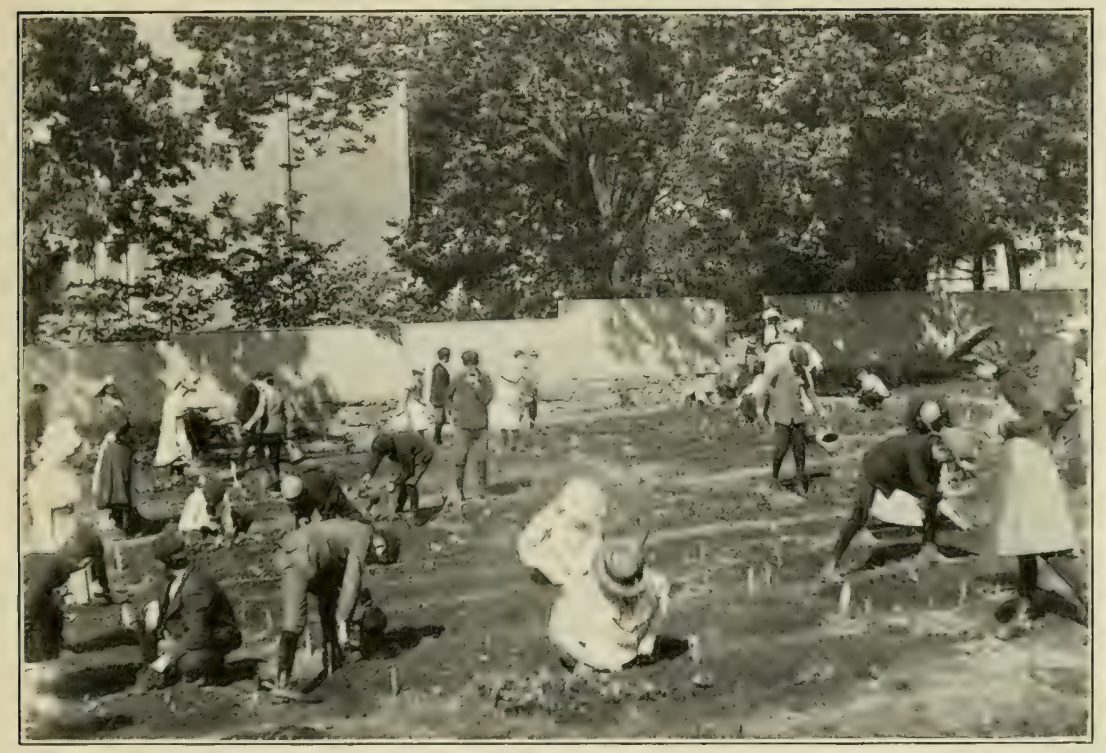

Fig. 1.-George Putnam School Gardens, Boston.

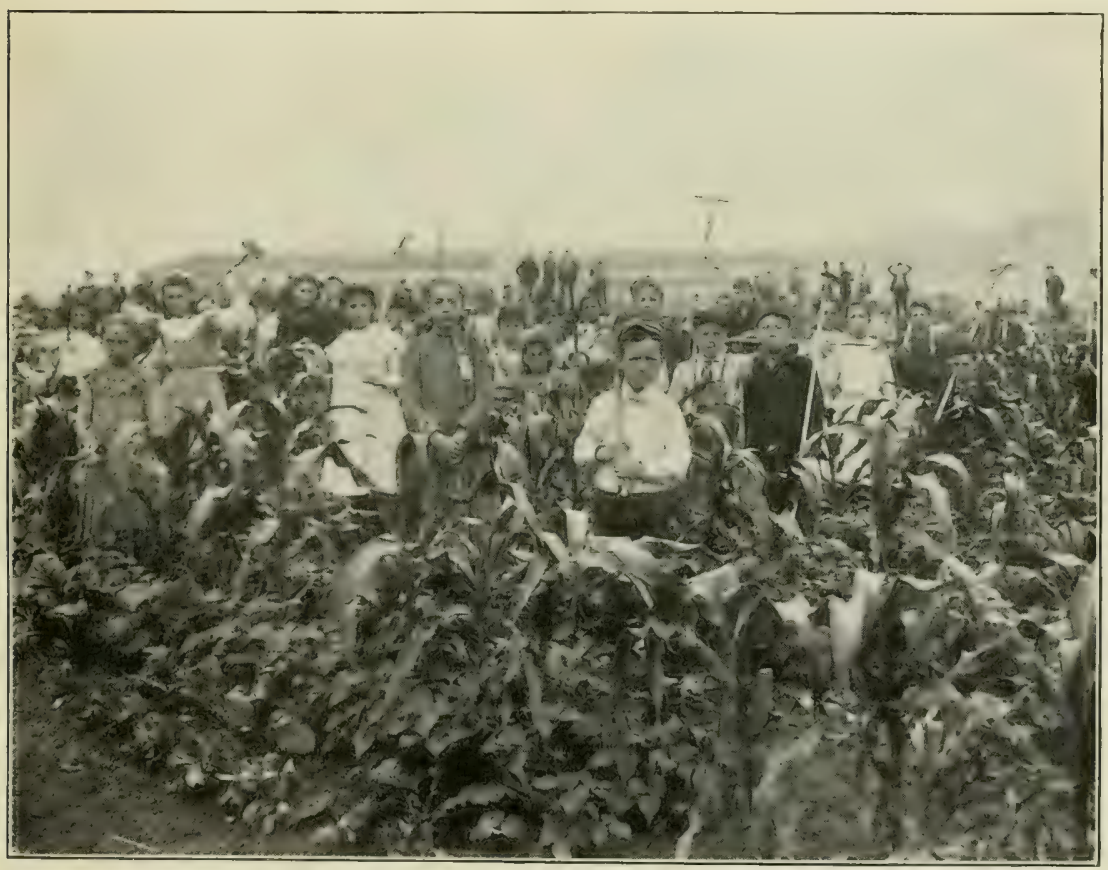

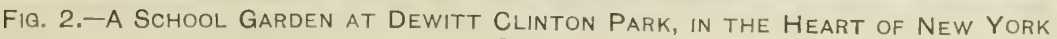
CITY. 

introduction of nature study and school-garden work. These subjects now constitute a part of the regular instruction and practice work in many of the normal schools in all parts of the Union (PI. VII, tig. 2).

A number of the State legislatures have passed laws recently whereby the public sehools are permitted or encouraged to provide instruction in agriculture. Such laws now exist in Alabama, Georgia, Illinois, Louisiana, Maryland, Michigan, Missouri, North Carolina, and Wisconsin. The State superintendents of public instruction are beginning to take an active interest in this subject, and at the last meeting of the National Educational Association in Boston a committee was appointed to consider, among other things, the teaching of agricultural subjects in the public schools. The agricultural work which is now being attempted in the public schools in different parts of the country includes the following:

(1) Nature study with plants, farm crops, domestic animals, soils, etc.

(2) School-garden work, including the growing of flowers, vines, and shrubbery for the improvement of school and home grounds and regetables in gardens at the schools or at home (Pl. VIII, figs. 1 and 2).

(3) The organization of clubs among rural-school children for making simple experiments with fertilizers and field crops.

(4) Lecture courses and institutes for rural-school children. 



\section{LIST OF PUBLICATIONS OF THE OFFICE OF EXPERIMENT STATIONS ON AGRICULTURAL EDUCATION.}

NoтE.-For those publications to which a price is affixed application should be made to the Superintendent of Documents, Washington D. C., the officer designated by law to sell Govermment publications.

\section{BULLETINS.}

Miscellaneous Bul. 1. Proceedings of the Second Annual Convention of the Association of American Agricultural Colleges and Experiment Stations, held at Knoxville, Tenn., January 1-3, 1889. Price, 10 cénts.

Miscellaneous Buls. 2, 3. Proceedings of the Annual Conventions of the Association of American Agricultural Colleges and Experiment Stations. 1890 and 1891. Not available.

Buls. 1, 5, 12, 13, 19. Organization Lists of the Agricultural Colleges and Experiment Stations in the United States. 1889-1894. Not available.

Buls. 23, 27, 39, $47,59,7+, 88,111,122,137$. Organization Lists of the Agricultural Colleges and Experiment Stations in the United States. 1895-1904. P'rice, 10 cents each.

Buls. $7,16,20,24,30,41,49,65,76,99,115,123,142$. Proceedings of the Ainnual Conventions of the Association of American Agricultural Colleges and Experiment Stations. 1891-1903. Prices, 5, 10, and 15 cents each.

Buls. 51, $64,78,97,114,128$. Statisties of the Land-Grant Colleges and Agricultural Experiment Stations in the United States for the years ended June 30, 1897-1902, inclusive. Price, 5 cents each.

Bul. 72. Farmers' Reading Courses. By L. H. Bailey, M. S., professor of horticulture, Cornell University. Pp. 36. 1899, Price, 5 cents.

Bul. 79. Farmers' Institutes: History and Status in the United States and Canada. By L. H. Bailey, of Cornell University. Pp. 34. 1900. Price, 5 cents.

Buls. 110, 120, 138. Proceedings of the Annual Meetings of the American Association of Farmers' Institute Workers. 1901-1903. Prices, 5 and 10 cents:

Bul. 127. Instruction in Agronomy at some Agricultural Colleges. By A. C. True and D. J. Crosby. Pp. 85, pls. 17, figs. 22. 1903. Price, 20 cents.

Bul. 135. Legislation Relating to Farmers' Institutes in the United States and the Province of Ontario, Canada. By John Hamilton, Farmers' Institute Specialist. Pp. 53. 1903. Price, 5 cents.

Bul. 139. Special and Short Courses in Agricultural Colleges. By D. J. Crosby. Pp. 59. Price, 5 cents.

\section{CIRCULARS.}

Cir. 27. Statistics of Agricultural Colleges and Experiment Stations. 1894. Pp. 18.

Cir. 32, revised. Report of Committee on Methods of Teaching Agriculture [first report]. Pp. 20.

Cir. 35. Statistics of Land-Grant Colleges and Agricultural Experiment Stations. 1896: Pp. 18.

Cir. 37, revised. Second report of the Committee on Methods of Teaching Agriculture. Pp. 4.

Cir. 39. Methods of Teaching Agriculture [third report of committee]. Pr. 7.

Cir. 41. Fourth Report of Committee on Teaching Agriculture. Pp. 7.

Cir. 42. A German Common School with a Garden. By C. B. Smith. Pp. 7 , figs. 2.

Cir. 45. Methods of Teaching Agriculture [fifth report of committee]. Pp. 8.

Cir. 49. Secondary Courses in Agriculture [seventh report of committee on teaching agriculture]. Pp. 10.

Cir. 51. List of State Directors of Farmers' Institutes and Institute Lecturers of the United States. By John Hamilton, Farmers' Institute Specialist. Pp. 23.

Cir. 52, revised. A Few Good Books and Bulletins on Nature Study, School Gardening, and Elementary Agriculture for Common Schools. By D. J. Crosby. Pp. 4.

Cir. 53. Report of the Committee on Rural Engineering of the Association of American Agricultural Colleges and Experiment Stations. Pp. 10.

Cir. 55. The Relation of Natural Sciences to Agriculture in a Four-Year College Course [eighth report of committee on methods of teaching agriculture]. P. 15. 
Education and Research in Agriculture in the Uniter States. By A. C. True. Reprinted from Yearbook of Department of Agriculture for 1894. Pp. 35.

Agricultural Education and Research in Belgium. By A. C. True. Reprinterl from Yearbook of Department of Agriculture for 1896. Pp. 10.

Popular Education for the Farmer in the United States. By A. C. True. Reprinted from Yearbook of Department of Agriculture for 1897. Pp. 12, pl. 1 .

Some Types of American Agricultural Colleges. By A. C. True. Reprinted from Yearbook of Department of Agriculture for 1898." Pp. 18, pls. 7.'

Agricultural Education in the United States. By A.C. True. Reprinted from Yearbook of Department of Agrieulture for 1899. Pp. 34 .

Agricultural Education in France. By C. B. Smith. Reprinted from Yearbook of Department of Agriculture for 1900. Pp. 16 .

Some Problems of the Rural Common School. By A. C. True. Reprinted from Yearbook of Department of Agriculture for 1901. Pp. 22, pl. 1, figs. 4.

Progress in Secondary Education in Agriculture. By A. C. True. Reprinted from Yearbook of Department of Agriculture for 1902.- Pp. 21, pls. 2.

Some Features of Recent Progress in Agricultural Edueation. By A. C. True. Reprinted from Annual Report of Office of Experiment Stations for 1902. Pp: 43.

Farmers' Institutes in the United States. By D. J. Crosby. Reprinted from Annual Report of Office of Experiment Stations for 1902, Pp. 20.

Progress in Agricultural Education, 1903. By A. C. True. Reprinted from Annual Report of Office of Experiment Stations for 1903. Pp. 65, pls. 24 .

Farmers' Institutes in the United States. By John Hamilton. Reprinted from Annual Report of Office of Experiment Stations for 1903. PP. 53.

Development of the Text-Book of Agriculture in North America. By L. H. Bailey. Reprinted from Annual Report of Oflice of Experiment Stations for 1903. Pp. 24.

Agricultural Economics as a Subject of Study in the Agricultural College. By K. I. Butterfield. Reprinted from Annual Report of Office of Experiment Stations for 1903. Pp. 6.

Instruction in Agriculture in Land-Grant Colleges and Schools for Colored Persons. By D.J. Crosby. Reprinted from Annual Report of Oftice of Experiment Stations for 1903. Pp. 31, pls. 6.

Statisties of Land-Grant Colleges and Agricultural Experiment Stations, 1903. By M. T. Spethmann. Reprinted from Annual Report of Office of Experiment Stations for 1903. Pp. 33.

Agricultural Associations in Belgium. By P. de Vuyst, Assistant Inspector of Agriculture of Belgium. Reprinted from Experiment Station Record, Yol. IX, No. 1. Pp. 21.

Agricultural Education and Research in the Scandinavian Countries and Finland. By F. W. Woll. Reprinted from Experiment Station Record, Vol. IX, Nos. 7 and 8. Pp. 606-616 and 703-719, figs, 4.

Rural Fconomics as a Subjeet of Undergrarluate Study. Reprinted from Experiment Station Record, Vol. XV, No. 8. Pp. 5. 

2.

+5. 